\title{
DAMPAK AKUNTABILITAS PEMERINTAHAN DESA TERHADAP PENGELOLAAN ALOKASI DANA DESA (Studi kasus Desa Jagaraga)
}

\author{
Kadek Isnayanti, Luh Budayani Sri Maherni, Made Putri Irayani \\ Jurusan Akuntansi, Universitas Pendidikan Ganesha, Singaraja, Bali, Indonesia
}

\begin{abstract}
Abstrak
Penelitian ini bertujuan untuk mengetahui kebijakan alokasi Dana Desa dalam Pembangunan di Desa Jagaraga, dampak alokasi dana desa terhadap pemberdayaan masyarakat dan kelembagaan desa, peran perangkat desa dalam pengelolaan dana desa, dan apa saja faktor penghambat serta faktor pendukung yang mempengaruhi pengelolaan Alokasi Dana Desa. Berdasarkan hasil penelitian ini menyatakan bahwa Kebijakan Alokasi Dana Desa terhadap Pemberdayaan Masyarakat dan Kelembagaan Desa Jagaraga terbagi menjadi 2 (dua), yaitu ADD untuk Operasional Pemerintah Desa desa dan belanja aparatur sebesar $30 \%$ dan ADD untuk Pemberdayaan Masyarakat sebesar $70 \%$. RKP desa berisi evaluasi pelaksanaan Rencana Kerja Pemerintah Desa (RKPDesa) tahun sebelumnya, prioritas program, kegiatan, dan anggaran desa yang dikelola oleh desa Rencana Kerja Pemerintah Desa (RKPDesa) menjadi dasar penetapan Anggaran Pendapatan dan Belanja Desa (APBDesa). Pelaksanaan Anggaran Pendapatan dan Belanja Desa terdiri dari : Prinsip Pelaksanaan Keuangan Desa, Pelaksanaan Penerimaan Pendapatan, Pelaksanaan Pengeluaran/Belanja, Pelaksanaan Pembiayaan.
\end{abstract}

Kata kunci: Akuntanbilitas, Pemerintahan Desa, Pengelolaan, Dana Desa

\begin{abstract}
This study aims to determine the policy of Village Fund allocation in Development in Jagaraga Village, the impact of village fund allocation on community empowerment and village institutions, the role of village officials in managing village funds, and what are the inhibiting factors and supporting factors that influence the management of Village Fund Allocation. Based on the results of this study stated that the Village Fund Allocation Policy on Community Empowerment and Institution of Jagaraga Village is divided into 2 (two), namely $A D D$ for Village Government Operations and apparatus spending by $30 \%$ and $A D D$ for Community Empowerment by $70 \%$. The village RKP contains an evaluation of the implementation of the Village Government Work Plan (RKPDesa) of the previous year, priority programs, activities, and village budgets managed by the village Village Government Work Plan (RKPDesa) as the basis for determining the Village Budget and Expenditure (APBDesa). The implementation of the Village Revenue and Expenditure Budget consists of: Principles for the Implementation of Village Finances, Implementation of Revenue Revenues, Implementation of Expenditures / Expenditures, Implementation of Financing.
\end{abstract}

Keywords: Accountability, Village Government, Management, Village Funds

\section{Pendahuluan}

Menurut Undang-Undang Nomor 6 Tahun 2014 Tentang Desa, yang dimaksud dengan Desa adalah kesatuan masyarakat hukum yang memiliki batas wilayah yang 
berwenang untuk mengatur dan mengurus urusan pemerintahan, kepentingan masyarakat setempat berdasarkan prakarsa masyarakat, hak asal usul, dan/atau hak tradisional yang diakui dan dihormati dalam sistem pemerintahan Negara Kesatuan Republik Indonesia.

Desa mempunyai peran untuk mengurusi serta mengatur sesuai dengan UndangUndang Nomor 6 Tahun 2014 tentang Desa yang salah satu pasalnya dijelaskan bahwa desa memiliki kewenangan dalam bidang penyelenggaraan pemerintahan, pembangunan, pembinaan kemasyarakatan dan pemberdayaan desa. Dalam hal ini desa diberikan wewenang yang luas untuk mengatur rumah tangganya sendiri sesuai dengan potensi desa yang dimiliki dalam rangka upaya peningkatan kualitas hidup dan kehidupan untuk sebesarbesarnya kesejahteraan masyarakat desa.Tentu saja wewenang yang luas tersebut tetap diatur sesuai dengan Undang-undang.Salah satu aspek yang ikut berperan dalam pengembangan desa adalah keuangan desa dan aset desa.

Berdasarkan Peraturan Menteri Dalam Negeri Nomor 113 Tahun 2014 tentang Pengelolaan Keuangan Desa menyatakan bahwa keuangan desa adalah semua hak dan kewajiban desa yang dapat dinilai dengan uang serta segala sesuatu berupa uang dan barang yang berhubungan dengan pelaksanaan hak dan kewajiban desa, selain itu keuangan desa tersebut harus dikelola berdasarkan asas-asas transparan, akuntabel, partisipatif, serta dilakukan dengan tertib dan disipilin anggaran.

Sedangkan aset desa adalah barang milik desa yang berasal dari kekayaan asli desa, dibeli atau diperoleh atas beban Anggaran Pendapatan dan Belanja Desa atau perolehan hak lainnya yang sah.Pemerintah dalam pengelolaan keuangan perlu menerapkan prinsip good governance yaitu akuntabilitas khususnya pada pengelolaan Alokasi Dana Desa (ADD).Menurut Abdul Halim dan Muhamad Ikbal (2012:83) akuntabilitas adalah kewajiban untuk memberikan pertanggungjawaban atau menjawab dan menerangkan kinerja dan tindakan seseorang/badan hukum atau pimpinan suatu organisasi kepada pihak yang memiliki hak atau berkewenangan untuk meminta keterangan atau pertanggungjawaban.Sedangkan menurut Mardiasmo (2012:46) akuntabilitas adalah sebuah kewajiban melaporkan dan bertanggungjawab atas keberhasilan ataupun kegagalan pelaksanaan misi organisasi dalam mencapai hasil yang telah ditetapkan sebelumnya, melalui media pertanggungjawaban yang dikerjakan secara berkala.Maka Secara garis besar mengenai penjelasan akuntabilitas dapat diambil kesimpulan bahwa akuntabilitas adalah merupakan pertanggungjawaban oleh lembaga yang diberi wewenang dalam mengelola sumber daya publik.

Pada penyelenggaraan pemerintahan desa di desa Jagaraga masih mengalami kendala khususnya dalam Pengelolaan Alokasi Dana Desa. Alokasi Dana Desa merupakan bagian dari dana perimbangan keuangan pusat dan daerah yang diterima oleh daerah atau kabupaten untuk desa paling sedikit 10 persen yang pembagiannya untuk desa secara proporsional dalam anggaran pendapatan dan belanja daerah (APBD) setelah dikurangi dana alokasi khusus. Maka intinya Alokasi Dana Desa adalah bagian keuangan desa yang diperoleh dari hasil bagi pajak daerah dan bagi bagian dari dana perimbangan keuangan pusat dan daerah yang diterima oleh kabupaten/kota untuk desa yang dibagikan secara proporsional. Itulah dana desa yang kini sedang menjadi isu besar ditingkat nasional.

Adapun hal yang menyebabkan kendala dalam Pengelolaan Alokasi Dana Desa di Desa Jagaraga yaitu seperti sumber Regulasi Transfer Anggaran Tidak sesuai dengan perencanaan atau tidak tepat waktu pengiriman, kurangnya staf dalam melakukan kegiatan, 
keterlambatan dalam pengesahan peraturan kepala daerah (Perkada) tentang pembagian Dana Desa (DD) dan Alokasi Dana Desa (ADD), Keterlambatan dalam Penetapan Anggaaran Pendapatan Dan Belanja Desa (APBDes), proses asistensi yang lama di kabupaten atau kota.

Dengan adanya permasalahan tersebut sehingga banyak hal yang harus dikaji berkaitan dengan pengelolaan Alokasi Dana Desa. Untuk mengatasi kendala tersebut Pemerintah desa di Desa Jagaraga ini melakukan strategi penanganan masalah Alokasi Dana Desa yaitu seperti meningkatkan kompetensi dan integritas pengelola dana desa (pelatihan terpadu), mengedepankan pencegahan daripada penindakan, menyelesaikan permasalahan pada hulu permasalahnnya, melibatkan peran serta masyarakat dalam pengawasan dana desa. sehingga kegiatan penelitian mengenai permasalahan tersebut sangat penting dilaksanakan, yaitu dengan melaksanakan penelitian untuk mencermati pengelolaan alokasi dana desa tepatnya di Desa Jagaraga.

Berdasarkan permasalahan diatas, adapun rumusan masalah yang dilakukan yaitu bagaimana kebijakan Alokasi Dana Desa dalam Pembangunan di Desa Jagaraga, bagaimana dampak alokasi dana desa terhadap pemberdayaan masyarakat dan kelembagaan desa, bagaimana peran perangkat desa dalam pengelolaan dana desa, dan apa saja faktor penghambat serta faktor pendukung yang mempengaruhi pengelolaan Alokasi Dana Desa.

\section{HasildanPembahasan}

\section{Kebijakan Alokasi Dana Desa dalam Pembangunan di Desa Jagaraga}

Desa Jagaraga adalah sebuah desa yang terletak di Kecamatan Sawan Kabupaten Buleleng Provinsi Bali.JAGARAGA, adalah sebuah desa yang terletak $+12 \mathrm{~km}$ sebelah timur Kota Singaraja, yang berada pada ketinggian + $100 \mathrm{~s} / \mathrm{d} 150$ meter diataspermukaan laut.Awal nama Desa Jagaraga adalah Jagat Sari yang berarti daerah hamparan bunga, wilayah Jagat Sari sebenarnya wilayah 2 (dua) desa yang terdahulu ada yaitu Desa Menyali disebelah selatan dan Desa Bungkulan disebelah utara. Data-data peninggalan desa-desa tersebut masih ada sekarang ini yaitu antara lain : Pura Puseh Menyali, yang berada disebelah timur Pura Dalem Desa Pakraman Jagaraga, sedangkan Pura Subak Bungkulan, yang berada disebelah barat Pura Dalem Desa Pakraman Jagaraga. Perubahan nama dari Jagat Sari menjadi Jagaraga, berawal dari kejadian hilangnya penari rejang dewa yang berada paling terakhir pada setiap upacara piodalan di Pura Puseh Menyali, melalui suatu pengamatan yang seksama, diketahuilah penari rejang dewa itu diambil oleh seorang pertapa digoa sebuah lereng tukad/sungai gelung sangsit dekat banjar abasan, yang mana petapa tersebut memperaktikkan ajian ilmu hitam penguat raga melalui darah seorang gadis perawan.

Untuk menjaga keselamatan diri masing-masing warga/penduduk Jagat Sari disekitar pada masa itu agar selalu mawas diri / jagra (Jaga-Ragane), agar tidak terganggu kehidupannya sehari-hari.Keadaan ini berlangsung lama, sampai akhirnya penguasa Buleleng Timur, dalam hal ini adalah Ki Pasek Bulian, mengutus seorang yang dianggap mampu mengatasi perusuh dari petapa itu. Beliau bernama I Gusti Tambahan, beliau sebenarnya berasal dari daerah Bangli, dalam perpindahannya ke Denbukit (Buleleng), 
beliau telah berjasa pada Ki Pasek Bulian hingga diberikanlah suatu daerah baru dan selanjutnya bernama Desa Kubutambahan. Melalui usaha yang keras dapatlah I Gusti Tambahan membunuh pertapa itu serta nama Jagat Sari setelahnya berkembang serta diganti namanya menjadi Jagaraga.

Di desa ini terdapat organisasi pemerintahan desa dimana lembaga pemerintahan tersebut bertugas mengelola wilayah tingkat desa. Pemerintahan daerah adalahpemerintah daerah yang menyelenggarakan urusan pemerintahan menurut asas otonomi dan tugas pembantuan dengan prinsip otonomi seluas-luasnya dalam sistem dan prinsip Negara Kesatuan Republik Indonesia. Pemberian otonomi luas kepada daerah diharapkan mampu meningkatkan daya saing dengan rasa keadilan dan kepatutan, serta mengutamakan kepentingan masyarakat setempat. Konsekuensi adanya ketentuan pelaksanaan otonomi desa, tersedianya dana yang cukup. Oleh karena itu, muncul adanya Peraturan Pemerintah Nomor 72 Tahun 2005 tentang Desa, bahwa dana perimbangan keuangan pusat dan daerah yang diterima oleh kabupaten/ kota yang dalam pembagiannya untuk tiap desa dibagikan secara proporsional yang disebut sebagai Alokasi Dana Desa (selanjutnya disingkat ADD)

Alokasi dana desa atau ADD merupakan dana yang harus dialokasikan oleh pemerintah Kabupaten untuk desa, yang bersumber dari bagian dana perimbangan keuangan pusat dan daerah yang diterima dari Kabupaten yang penggunaannya $30 \%$ untuk belanja aparatur dan operasional dan $70 \%$ untuk belanja publik dan pemberdayaan masyarakat (Sanusi dan Djumlani, 2014: 78). Menurut peraturan Menteri Dalam Negeri Nomor 37 Tahun 2007 tentang Pedoman Pengolahan keuangan Desa pada pasal 18 bahwa Alokasi Dana Desa berasal dari APBD Kabupaten/Kota yang bersumber dari bagian Dana Perimbangan Keuangan Pusat dan Daerah yang diterima oleh Kabupaten/Kota untuk desa paling sedikit $10 \%$. Jika dilihat dari tujuannya, ADD merupakan lanjutan dari program bantuan desa yang disediakan oleh pemerintah pusat dalam bentuk inpres pembangunan desa.Sejak otonomi daerah ADD dialokasikan melalui APBDesa (Solekhan, 2012: 80). Jadi, semakin tinggi tanggungjawab pengelolaan ADD maka akuntabilitas pengelolaan ADD akan semakin baik juga. Sebaliknya, jika pengelolaan ADD rendah maka akuntabilitas pengelolaan ADD akan tidak baik.

Berikut ini merupakan contoh tabel pendapatan desa Jagaraga pada tahun 2016

\begin{tabular}{|l|l|}
\hline PENDAPATAN & $\mathbf{2 . 6 1 4 . 6 8 8 . 8 8 1 , 7 1}$ \\
\hline Pendapatan Asli Desa & $\mathbf{3 . 3 2 5 . 0 0 0 , 0 0}$ \\
\hline Hasil Usaha & 0,00 \\
\hline Swadaya, Partisipasi dan Gotong Royong & 0,00 \\
\hline Lain-lain Pendapatan Asli Desa yang Sah & $3.325 .000,00$ \\
\hline & \\
\hline Pendapatan Transfer & $\mathbf{2 . 6 1 1 . 3 6 3 . 8 8 1 , 7 1}$ \\
\hline Dana Desa & $\mathbf{6 2 2 . 3 1 9 . 4 7 9 , 1 7}$ \\
\hline $\begin{array}{l}\text { Bagian dari hasil Pajak dan Retribusi } \\
\text { daerah kabupaten/kota }\end{array}$ & $\mathbf{8 4 . 3 8 6 . 2 5 9 , 9 6}$ \\
\hline Bagi hasil Pajak daerah & $72.851 .737,38$ \\
\hline Bagi hasil Retribusi daerah & $11.534 .522,58$ \\
\hline & \\
\hline
\end{tabular}




\begin{tabular}{|l|l|} 
Alokasi Dana Desa & $\mathbf{5 7 8 . 6 5 8 . 1 4 2 , 5 8}$ \\
\hline Bantuan Keuangan & $\mathbf{1 . 3 2 6 . 0 0 0 . 0 0 0 , 0 0}$ \\
\hline Bantuan Provinsi & $\mathbf{1 . 3 2 6 . 0 0 0 . 0 0 0 , 0 0}$ \\
\hline $\begin{array}{l}\text { BKK Operasional Pemerintah Desa, Desa } \\
\text { Pakraman dan Subak/Subak Abian }\end{array}$ & $306.000 .000,00$ \\
\hline BKK Gerbang Sadu Mandara (GSM) & $1.020 .000 .000,00$ \\
\hline & $\mathbf{0 , 0 0}$ \\
\hline Bantuan Kabupaten/ Kota & $\mathbf{0 , 0 0}$ \\
\hline & 0,00 \\
\hline Pendapatan Lain-lain & 0,00 \\
\hline $\begin{array}{l}\text { Hibah dan Sumbangan dari Pihak ke-3 yang } \\
\text { tidak mengikat }\end{array}$ & $\mathbf{2 . 6 1 4 . 6 8 8 . 8 8 1 , 7 1}$ \\
\hline Lain-lain Pendapatan Desa Yang Sah & \\
\hline JUMLAH PENDAPATAN &
\end{tabular}

Kehadiran undang - undang tentang Desa tersebut disamping merupakan penguatan status desa sebagai pemerintahan masyarakat, sekaligus juga sebagai basis untuk memajukan masyarakat dan pemberdayaan masyarakat desa.Untuk itulah pemerintah mengeluarkan kebijakan yaitu pembentukan Alokasi Dana Desa (ADD) sebagai perwujudan dari desentralisasi keuangan menuju desa yang mandiri.

Kepala desa dalam rangka melaksanakan pengelolaan keuangan desa, dibantu oleh Pelaksana Teknis Pengelolaan Keuangan Desa (PTPKD). PTPKD dari unsur Perangkat Desa terdiri dari: a) Sekretaris Desa adalah bertindak selaku koordinator pelaksanaan pengelolaan keuangan desa. b) Kepala Seksi adalah unsur dari pelaksanaan teknis kegiatan dengan bidangnya. c) Bendahara adalah unsur staf sekretaris desa yang membidangi urusan administrasi keuangan untuk menatausahaan keuangan desa. Dalam pengelolaan keuangan desa, kepala desa melimpahkan kewenangan kepada perangkat desa yang ditunjuk.Kepala Desa mengungkapkan Alokasi Dana Desa adalah dana yang bersumber dari APBD yang dialokasikan dengan tujuan pemerataan kemampuan keuangan antar desa untuk mendanai kebutuhan desa dalam rangka penyelenggaraan pemerintahan dan pelaksanaan pembangunan serta pelayanan masyarakat.

Kebijakan alokasi dana desa yang dilakukan sesuai dengan RPJMDes (Rencana Pembangunan Jangka Menengah Desa) atau sesuai dengan pembangunan yang dibutuhkan di desa. Dengan adanya alokasi dana desa atau ADD segala kegiatan di desa bisa didanai sesuai dengan perencanaan di desa. Setelah Rencana Pembangunan Jangka Menengah Desa (RPJMDes) disetujui oleh pihak BPD dan Kepala Desa setelah melalui musyawarah desa yang dihadiri oleh seluruh perangkat desa dan beberapa perwakilan dari masyarakat di desa Jagaraga yang kemudian akan dijadikan sebagai peraturan desa. kemudiansetelah rencana tersebut disetujui maka langkah selanjutnya yaitu ke Rencana Kegiatan Pembangunan (RKP) dan menganggarkan Anggaran Pendapatan Belanja Desa (APBDes). Peraturan desa inilah yang nantinya akan dijadikan sebagai pedoman dalam melaksanakan kebijakan alokasi dana desa dalam pembangunan desa Jagaraga sendiri guna meningkatkan taraf hidup atau mensejahterakan masyarakatnya serta memajukan desanya baik di bidang pembangunan sarana dan prasarana di desa maupun pembangunan 
mental. Keberhasilan akuntabilitas ADD dipengaruhi oleh isi kebijakan dan konteks implementasi di desa Jagaraga. Namun di dalam pelaksanaannya tergantung bagaimana pemerintah melakukan pengawasan dan pembinaan terhadap pengelolaan ADD.

\section{Dampak Alokasi Dana Desa Terhadap Pemberdayaan Masyarakat dan Kelembagaan Desa Jagaraga}

Penggunaan ADD terbagi menjadi 2 (dua), yaitu ADD untuk Operasional Pemerintah Desa desa dan belanja aparatur sebesar $30 \%$ dan ADD untuk Pemberdayaan Masyarakat sebesar $70 \%$. Pemberdayaan masyarakat dengan penggunaan dana ADD sebagian besar masih dalam bentuk fisik seperti membangun drainase atau pengatusan dan meningkatkan pembangunan infrastruktur berdasarkan program skala prioritas bagi masing-masing dusun di desa Jagaraga. Hal ini menunjukkan bahwa proses pencairandana ADD adanya kesesuaian kebutuhan oleh kelompok-kelompok sasaran dengan apa yang ditawarkan oleh program ini. Dimaksudkan bahwa kelompok sasaran akan mendapatkan manfaat dari apa yang ditawarkan oleh program, sehingga kebutuhannya dapat terpenuhi (Kuncoro, 2007: 214).Segala penerimaan pemberdayaan sangat berdampak kepada masyaarakat dan kelembagaan desa Jagaraga ini. Di Desa Jagaraga, manfaat alokasi dana desa ini sangat berpengaruh besar terhadap perputaran ekonomi masyarakat desa melalu pemberdayaan.

Kepala desa Jagaraga menjelaskan bahwa ADD bermanfaat untuk mengurangi beban pemerintah desa dalam melakukan pembangunan, dapat meningkatkan pemberdayaan dan pembinaan pada masyarakat desa, dan meringankan beban masyarakat dalam pembangunan dan kesejahteraannya.Berdasarkan hasil wawancara yang telah diuraikan tersebut dapat diketahui bahwa ADD sangat bermanfaat bagi pembangunan desa dan untuk melakukan pembinaan pada masyarakat sebagai suatu upaya pemberdayaan masyarakat.

\section{Peran Perangkat Desa dalam Pengelolaan Dana Desa Jagaraga}

Perangkat desa sebagai salah satuunsur pelaku desa memiliki peran pentingtersendiri dalam mengembangkankemajuan bangsa melalui desa.Perangkatdesa merupakan bagian dari unsurpemerintah desa yang terdiri darisekretaris desa dan perangkat desa lainnyayang merupakan aparatur desa dibawahnaungan kepala Desa (Gunawan, 2013).Perangkat desa dituntut dapat mengeloladan mengembangkan masyarakat dansegala sumber daya yng kita miliki secarabaik (Good Governance) yang bercirikandemokratis juga desentralistis.

Akuntabilitas keuangan desa tidak hanya bersifat horizontal antara pemerintah desa dengan Badan Permusyawaratan Desa (BPD), tetapi juga harus bersifat vertikal antara kepala desa dengan masyarakat desa dan atasan kepala desa.Dokumen publik tentang pengelolaan keuangan desa harus dapat diakses oleh masyarakat desa, serta tidak diskriminasi terhadap satu golongan tertentu dengan pengelolaan keuangan desa. Siklus pengelolaan keuangan desa berdasarkan Permendagri No. 113 Tahun 2014 tentang Pengelolaan Keuangan Desa terdiri dari perencanaan, pelaksanaan dan penatausahaan, serta pelaporan dan pertanggungjawaban.

Perencanaan adalah sebagai perhitungan dan penentuan tentang apa yang dijalankan dalam rangka mencapai tujuan tertentu dimana menyangkut tempat, oleh siapa pelaku itu atau pelaksanaan tata cara mencapai tujuan tersebut. Dari pernyataan tersebut perencanaan dapat diartikan sebagai pemilihan sekumpulan kegiatan dan pemusatan 
selanjutnya apa yang harus dilakukan, kapan, bagaimana, dan oleh siapa menurut Nurcholis dalam Wida (2016:11). Dokumen perencanaan keuangan desa meliputi Rencana Pembangunan Jangka Menengah Desa (RKJMDesa) dan Rencana Kerja Pemerintah Desa (RKPDesa) yang berpedoman kepada perencanaan pembangunan desa yang disusun hasil kesepakatan dalam musyawarah desa.PenyusunanRencana Pembangunan Jangka Menengah Desa (RPJMDesa) dan Rencana Kerja Pemerintah Desa (RKPDesa) dilakukan secara partisipatif dalam forum musyawarah perencanaan pembangunan desa yang melibatkan Badan Permusyawaratan Desa (BPDesa) dan unsur masyarakat desa.Rencana Pembangunan Jangka Menengah Desa (RPJMDesa) memuat penjabaran visi dan misi kepala desa terpilih, rencana penyelenggaraan pemerintahan desa, pelaksanaan pembangunan, pembinaan kemasyarakatan, pemberdayaan masyarakat dan arah kebijakan perencanaan pembangunan desa.Rencana Pembangunan Jangka Menengah (RPJM) Desa mengacu pada Rencana Pembangunan Jangka Menengah (RPJM) kabupaten/kota dengan mempertimbangkan kondisi objektif desa dan prioritas pembangunan kabupaten/kota.Rencana Pembanguna Jangka Menengah (RPJM) desa ditetapkan dalam jangka waktu paling lama tiga bulan terhitung sejak pelantikan Kepala Desa.Rencana Kerja Pemerintah Desa (RKPDesa) merupakan penjabaran dari Rencana Pembangunan Jangka Menengah (RPJM) desa untuk jangka waktu satu tahun.Rencana Kerja Pemerintah Desa (RKPDesa) memuat rencana penyelenggaraan pemerintahan desa, pelaksanaan pembangunan desa, pembinaan kemasyarakatan, pemberdayaan masyarakat desa. RKP desa berisi evaluasi pelaksanaan Rencana Kerja Pemerintah Desa (RKPDesa) tahun sebelumnya, prioritas program, kegiatan, dan anggaran desa yang dikelola oleh desa maupun melalui kerjasama antara desa/pihak ketiga serta kewenangan penugasan dari tingkatan pemerintah yang lebih tinggi. Rencana Kerja Pemerintah Desa (RKPDesa) menjadi dasar penetapanAnggaran Pendapatan dan Belanja Desa (APBDesa).

Menurut Permendagri 113 Tahun 2014 Pelaksanaan Anggaran Pendapatan dan Belanja Desa terdiri dari :

1) Prinsip Pelaksanaan Keuangan Desa

Dalam pelaksanaan keuangan desa, terdapat beberapa prinsip umum yang harus ditaati yang mencakup penerimaan dan pengeluaran.Prinsip itu diantaranya bahwa seluruh penerimaan dan pengeluaran desa dilaksanakan melalui Rekening Kas Desa. Pencairan dana dalam Rekening Kas Desa ditandatangani oleh Kepala Desa dan Bendahara Desa. Namun khusus bagi desa yang belum memiliki pelayanan perbankan di wilayahnya maka pengaturannya lebih lanjut akan ditetapkan oleh pemerintah kabupaten/kota.

2) Pelaksanaan Penerimaan Pendapatan

Pelaksanaan penerimaan pendapatan yaitu proses menerima dan mencatat pendapatan desa. Pendapatan desa yang bersifat Pendapatan Asli Desa berasal dari masyarakat dan lingkungan desa, sedangkan pendapatan transfer berasal dari pemerintah supra desa. Pihak yang terkait dalam proses penerimaan pendapatan adalah pemberi dana (Pemerintah Pusat/Prov/Kab/Kota, Masyarakat, Pihak ketiga), Penerima Dana (Bendahara Desa/Pelaksana Kegiatan/Kepala Dusun) dan bank.

3) Pelaksanaan Pengeluaran/Belanja

Belanja Desa diprioritaskan untuk memenuhi kebutuhan pembangunan yang disepakati dalam Musyawarah Desa dan sesuai dengan prioritas Pemerintah baik pemerintah 
pusat maupun pemerintah provinsi/kabupaten/kota. Hal tersebut seluruhnya tertuang dalam Rencana Kerja Pemerintah Desa yang pelaksanaannya akan diwujudkan melalui Anggaran Pendapatan dan Belanja Desa. Setelah Anggaran Pendapatan dan Belanja Desa ditetapkan dalam bentuk Peraturan Desa, program dan kegiatan sebagaimana yang telah direncanakan baru dapat dilaksanakan.Hal ini dikecualikan untuk Belanja Pegawai yang bersifat mengikat dan operasional perkantoran yang diatur dalam Keputusan Kepala Desa.Dengan adanya ketentuan dari kepala desa tersebut, maka belanja pegawai dan operasional dapat dilakukan tanpa perlu menunggu penetapan Anggaran Pendapatan dan Belanja Desa.Pelaksanaan Anggaran Pendapatan dan Belanja Desa dilakukan sesuai dengan kewenangan yang dimiliki oleh desa berdasarkan ketentuan yang berlaku.

4) Pelaksanaan Pembiayaan

Pelaksanaan Pembiayaan mencakup Penerimaan Pembiayaan dan Pengeluaran Pembiayaan.

a. Penerimaaan Pembiayaan

Penerimaan Pembiayaan mencakup SiLPA Tahun sebelumnya, Pencairan Dana Cadangan dan hasil Penjualan Kekayaan Desa yang Dipisahkan.Sisa Lebih Perhitungan Anggaran adalah penerimaan pembiayaan yang digunakan untuk mendanai pelaksanaan kegiatan tahun berjalan yang berasal dari pelampauan penerimaan pendapatan dan penghematan belanja tahun sebelumnya. Pencairan Dana Cadangan merupakan kegiatan pencairan dana dari rekening dana cadangan ke rekening desa yang dilakukan sesuai Peraturan Desa yang mengatur hal tersebut. Sedangkan penerimaan pembiayaan yang berasal dari Hasil Penjualan Kekayaan Desa yang Dipisahkan diperoleh dari realisasi penjualan aset/kekayaan desa kepada pihak ketiga.

b. Pengeluaran Pembiayaan

Pengeluaran Pembiayaan diantaranya Pembentukan Dana Cadangan dan Penyertaan Modal Desa.Menurut Permendagri 113 Tahun 2014 Penatausahaan Keuangan Desa adalah kegiatan pencatatan yang khususnya dilakukan oleh Bendahara Desa.Bendahara Desa wajib melakukan pencatatan terhadap seluruh transaksi yang ada berupa penerimaan dan pengeluaran.Bendahara Desa melakukan pencatatan secara sistematis dan kronologis atas transaksi-transaksi keuangan yang terjadi. Penatausahaan keuangan desa yang dilakukan oleh Bendahara Desa dilakukan dengan cara sederhana, yaitu berupa Pembukuan belum menggunakan jurnal akuntansi. Penatausahaan baik penerimaan kas maupun pengeluaran kas, Bendahara Desa menggunakan: 1) Buku Kas Umum; 2) Buku Kas Pembantu Pajak; dan 3) Buku Bank. c. Pelaporan dan Pertanggungjawaban.

Menurut Permendagri 113 Tahun 2014 dalam melaksanakan tugas, kewenangan, hak, dan kewajibannya dalam pengelolaan keuangan desa, kepala desa memiliki kewajiban untuk menyampaikan laporan.Laporan tersebut bersifat periodik semesteran dan tahunan, yang disampaikan ke Bupati/Walikota dan ada juga yang disampaikan ke BPD. Rincian laporan sebagai berikut: 1) Laporan kepada Bupati/Walikota (melalui camat):

a) Laporan Semesteran Realiasasi Pelaksanaan Anggaran Pendapatan dan Belanja Desa. Laporan Realisasi Pelaksanaan APB Desa Semester Pertama menggambarkan realisasi pendapatan, belanja dan pembiayaan selama semester I dibandingkan dengan 
target dan anggarannya, sedangkan Laporan Realisasi Pelaksanaan Anggaran Pendapatan dan Belanja Desa Semester Akhir Tahun mengambarkan Realisasi pendapatan, belanja dan pembiayaan sampai dengan akhir Tahun, jadi bersifat akumulasi hingga akhir tahun anggaran.

b) Laporan Pertanggungjawaban Realisasi Pelaksanaan Anggaran Pendapatan dan Belanja Desa kepada Bupati/Walikota setiap akhir tahun anggaran.Laporan Pertanggungjawaban Realisasi Pelaksanaan APB Desa Setiap Akhir Tahun Anggaran disampaikan kepada Bupati/Walikota melalui camat terdiri dari Pendapatan, Belanja, dan Pembiayaan yang telah ditetapkan dengan Peraturan Desa. Setelah Pemerintah Desa dan BPD telah sepakat terhadap Laporan Pertanggungjawaban Realisasi Pelaksanaan APB Desa dalam bentuk Peraturan Desa, maka Perdes ini disampaikan kepada Bupati/Walikota sebagai bagian tidak terpisahkan dari Laporan Penyelenggaraan Pemerintahan Desa. Laporan Pertanggungjawaban Realisasi Pelaksanaan APB Desa sebagaimana tercantum dalam pada pasal 41 Permendagri 113/2014, disampaikan paling lambat 1 (satu) bulan setelah tahun anggaran berkenaan.

c) Laporan Realisasi Penggunaan Dana Desa Laporan Realisasi Penggunaan Dana Desa disampaikan kepada bupati/walikota setiap semester. Penyampaian laporan realisasi penggunaan Dana Desa dilakukan: 1) Untuk semester I paling lambat minggu keempat bulan Juli tahun anggaran berjalan. 2) Untuk semester II paling lambat minggu keempat bulan Januari tahun anggaran berikutnya. 3) Laporan kepada Badan Permusyawaratan Desa (BPD)

Menurut Permendagri No 113 Tahun 2014 pertanggungjawaban terdiri dari: a) Kepala desa menyampaikan laporan pertanggungjawaban realisasi pelaksanaan APBDesa kepada Bupati/Walikota melalui camat setiap akhir tahun anggaran. Laporan pertanggungjawaban pelaksanaan realisasi pelaksanaan APBDesa terdiri dari pendapatan, belanja, dan pembiayaan. Laporan ini ditetapkan peraturan desa dan dilampiri: 1) Format Laporan Pertanggungjawaban Realisasi Pelaksanaan APBDesa Tahun anggaran berkenaan. 2) Format Laporan Kekayaan Milik Desa per 31 Desember Tahun Anggaran berkenaan. 3) Format Laporan Program Pemerintah dan Pemerintah Daerah yang masuk ke Desa. b) Laporan pertanggungjawaban realisasi pelaksanaan APBDesa sebagaimana dimaksud diatas, disampaiakan paling lambat 1 (satu) bulan setelah akhir tahun anggaran berkenaan.

Musyawarah Perencanaan Pembangunan (Musrembang) Desa diadakan untuk membahas dan menyepakati rancangan RPJMDes serta menyepakati prioritas kebutuhan atau kegiatan desa yang akan menjadi bahan penyusunan Rencana Kerja Pembangunan Desa (RKPDes). Rencana Kerja Pembangunan Desa (RKPDes) merupakan penjabaran dari Rencana Pembangunan Jangka Menengah Desa untuk jangka waktu 1 (satu) tahun. Rencana Kerja Pembangunan Desa (RKPDes) yang telah disusun ini akan menjadi dasar dalam penetapan Anggaran Pendapatan dan Belanja Desa (APBDes) tetapi sebelumnya sekretaris desa menyusun rancangan peraturan desa tentang APBDes tersebut untuk disampaikan kepada Kepala Desa. Peraturan Desa tentang APBDes akan disepakati oleh Kepala Desa bersama BPD.

Menurut Undang-Undang Nomor 6Tahun 2014 tentang Desa Pasal 25 bahwaPemerintah Desa adalah Kepala Desa atauyang disebut dengan nama lain dan yangdibantu oleh perangkat desa atau yangdisebut dengan nama lain. Dalam 
ilmumanajemen pembantu pimpinan disebutstaf.Staf profesional diartikan sebagaipegawai yaitu pimpinan yang memilikikeahlian dalam bidangnya,bertanggungjawab, dan berperilakuprofesional dalam menjalankan tugasnya.Selain itu seluruh komponen desa tersebut ikut melaksanakan kegiatan sesuai dengan proporsi tugas pokok dan fungsi masing-masing perangkat desa.

\section{Faktor Penghambat Serta Pendukung yang Mempengaruhi Pengelolaan ADD Desa Jagaraga}

Keberhasilan akuntabilitas ADD dipengaruhi oleh isi kebijakan dan konteks implementasinya. Namun di dalam pelaksanaannya tergantung bagaimana pemerintah melakukan pengawasan dan pembinaan terhadap pengelolaan ADD. Selain itu ada pula faktor-faktor yang mempengaruhi pengelolaan alokasi dana desa Jagaraga baik itu faktor penghambat maupun faktor pendukung.

Faktor penghambat yang mempengaruhi pengelolaan ADD di desa Jagaraga antara lain:

1. Dari wawancara dijelaskan bahwa salah satu faktor penghambat dalam pengelolaan ADD adalah rendahnya sumber daya manusia (SDM) perangkat desa. Namun menurut sumber referensi, Suparman (2014) mengungkapkan faktor-faktor yang memengaruhi keberhasilan pelaksanaan program ADD dalam pemberdayaan masyarakat desa diantaranya: faktor Sumber Daya Manusia (SDM), sosialisasi dan penyaluran dana, serta koordinasi yang masih belum sesuai dengan harapan yang diinginkan sehingga menyebabkan proses implementasi program Alokasi Dana Desa (ADD) di desa Jagaraga tidak berjalan dengan optimal. Hasil temuan penelitian Irma (2015) mengindikasikan bahwa pengelolaan administrasi keuangan ADD belum sepenuhnya sesuai dengan ketentuan peraturan daerah.

2. Regulasi transfer anggaran tidak sesuai dengan perencanaan atau bisa dikatakan tidak tepat waktu. Dengan kurangnya kesesuaian perencanaan di tingkat desa dan kecamatan, maka akan mempersulit langkah desa untuk mencapai tujuan yang diharapkan.

3. Kurangnya staf dalam melaksanakan kegiatan. Karena kekurangan staf yang handal dalam melaksanakan kegitan tersebut maka tidak dapat berjalan dengan lancar, hal ini yang menyebabkan atau dapat menghambat jalannya kegiatan.

4. Rendahnya kompetensi yang dimiliki aparat desa dibuktikan dengan adanya beberapa orang aparatur pemerintah desa yang belum menguasai dengan baik pemanfaatan teknologi komputerisasi dalam mendukung efektivitas pembuatan laporan pertanggungjawaban kegiatan yang dibiayai oleh dana ADD.

Mengatasi kurangnya pemahaman aparatur desa dalam mengimplementasikan program ADD, maka perlu adanya pelatihan pengelolaan ADD dari tim pendamping tingkat kecamatan kepada pelaksana teknis pengelolaan ADD. Keterbatasan penelitian ini pada satu desa dan penggalian data hanya pada aparatur pemerintah desa dan tidak bersumber pada masyarakata desa yang terkait dan aparatur Kecamatan yang bertanggungjawab pada pengelolaan Alokasi Dana Desa.

Sedangkan faktor pendukung yang mempengaruhi pengelolaan ADD di desa Jagaraga antara lain:

1. Adanya swadiaya murni. Sebenarnya swadaya murni ini menyangkut dan menjangkau segala aspek aktivitas masyarakat dalam bentuk partisipasi seperti kewajiban 
masyarakat terkait tradisi adat, kewajiban relegi, kewajiban social dan semua ini harus diadministrasikan. Bentuk administrasi swadaya murni adalah dapat dipakai sebagai tolak ukur sejauh mana partisipasi masyarakat dalam memajukan desanya serta dapat dipakai sebagai alat korelasi untuk melihat tingkat pertumbuhan ekonomi masyarakatnya.

2. Pendapatan asli desa. Alokasi dana desa di setiap desa di kecamatan sawan sendiri berbeda-beda tergantung dari sumber pendapatan asli desa (PADes). Sumber pendapatan desa Jagaraga untuk tahun anggaran 2016 terdiri atas: pendapatan yang terdiri dari pendapatan asli desa sebesar Rp 3.325.000, dana desa sebesar Rp 622.319.479,17, bagian dari hasil pajak dan retribusi daerah kabupaten/kota sebesar Rp 84.386.259,96 yang mana pembagiannya $\mathrm{Rp} 72.851 .737,38$ bagi hasil pajak daerah dan $\mathrm{Rp}$ 11.534.522,58 untuk bagi hasil retribusi daerah, Alokasi dana desa sebesar Rp 578.658.142,58, bantuan keuangan sebesar Rp 1.326.000.000 yang terinci dari BKK Operasional Pemerintah Desa, desa pakraman dan subak/subak Abian sebesar Rp 306.000.000 dan BKK Gedung Sadu Mandara (GSM) sebesar Rp 1.020.000.000, sehingga total jumlah Pendapatan yaitu sebesar Rp 2.614.688.881,71. Itu merupakan data pendapatan tahun 2016.

\section{Simpulandan Saran}

\section{Simpulan}

Berdasarkan hasil penelitian diatas maka dapat disimpulkan bahwa Kebijakan Alokasi Dana Desa dalam Pembangunan Desa Jagaraga, harus dialokasikan oleh pemerintah Kabupaten untuk desa, yang bersumber dari bagian dana perimbangan keuangan pusat dan daerah yang diterima dari Kabupaten yang penggunaannya $30 \%$ untuk belanja aparatur dan operasional dan $70 \%$ untuk belanja publik dan pemberdayaan masyarakat. Dengan adanya alokasi dana desa segala kegiatan di desa bisa didanai sesuai dengan perencanaan desa. Peraturan desa inilah yang nantinya akan dijadikan sebagai pedoman dalam melaksanakan kebijakan alokasi dana desa dalam pembangunan desa Jagaraga sendiri guna meningkatkan tarif hidup atau mensejahterakan masyarakatnya serta memajukan desanya baik di bidang pembangunan sarana dan prasarana di desa maupun pembangunan mental. Keberhasilan akuntabilitas ADD dipengaruhi oleh isi kebijakan dan konteks implementasi di desa Jagaraga. Namun di dalam pelaksanaannya tergantung bagaimana pemerintah melakukan pengawasan dan pembinaan terhadap pengelolaan ADD.

Dampak Alokasi Dana Desa Terhadap Pemberdayaan Masyarakat dan Kelembagaan Desa Jagaraga terbagi menjadi 2 (dua), yaitu ADD untuk Operasional Pemerintah Desa desa dan belanja aparatur sebesar $30 \%$ dan ADD untuk Pemberdayaan Masyarakat sebesar $70 \%$. Segala penerimaan pemberdayaan sangat berdampak kepada masyaarakat dan kelembagaan desa Jagaraga ini. Di Desa Jagaraga, manfaat alokasi dana desa ini sangat berpengaruh besar terhadap perputaran ekonomi masyarakat desa melalu pemberdayaan. Kepala desa Jagaraga menjelaskan bahwa ADD bermanfaat untuk mengurangi beban pemerintah desa dalam melakukan pembangunan, dapat meningkatkan pemberdayaan dan pembinaan pada masyarakat desa, dan meringankan beban masyarakat dalam pembangunan dan kesejahteraannya. 
Peran Perangkata Desa dalam Pengelolaan Dana Desa Jagaraga. RKP desa berisi evaluasi pelaksanaan Rencana Kerja Pemerintah Desa (RKPDesa) tahun sebelumnya, prioritas program, kegiatan, dan anggaran desa yang dikelola oleh desa maupun melalui kerjasama antara desa/pihak ketiga serta kewenangan penugasan dari tingkatan pemerintah yang lebih tinggi. Rencana Kerja Pemerintah Desa (RKPDesa) menjadi dasar penetapan Anggaran Pendapatan dan Belanja Desa (APBDesa). Pelaksanaan Anggaran Pendapatan dan Belanja Desa terdiri dari : Prinsip Pelaksanaan Keuangan Desa, Pelaksanaan Penerimaan Pendapatan, Pelaksanaan Pengeluaran/Belanja, Pelaksanaan Pembiayaan.

Faktor yang memengaruhi keberhasilan pelaksanaan program ADD dalam pemberdayaan masyarakat desa diantaranya: faktor Sumber Daya Manusia (SDM), sosialisasi dan penyaluran dana, serta koordinasi yang masih belum sesuai dengan harapan yang diinginkan sehingga menyebabkan proses implementasi program Alokasi Dana Desa (ADD) di desa Jagaraga tidak berjalan dengan optimal, Regulasi transfer anggaran tidak sesuai dengan perencanaan atau bisa dikatakan tidak tepat waktu, Kurangnya staf dalam melaksanakan kegiatan, Rendahnya kompetensi yang dimiliki aparat desa dibuktikan dengan adanya beberapa orang aparatur pemerintah desa yang belum menguasai dengan baik pemanfaatan teknologi komputerisasi dalam mendukung efektivitas pembuatan laporan pertanggungjawaban kegiatan yang dibiayai oleh dana ADD. Sedangkan faktor pendukung yang mempengaruhi pengelolaan ADD di desa Jagaraga antara lain :Adanya swadiaya murni, Pendapatan Asli Desa, Sumbangan pihak ketiga yang tidak mengikat.

\section{Saran}

Dari simpulan diatas maka kami dari pihak peneliti ingin memberikan saran dan masukan yang mungkin berguna bagi Pemerintahan Desa Di Jagaraga agar lebih meningkatkan perannya dalam penyelenggaraan otonomi desa melalui pendidikan, penyuluhan, dan pelatihan sehingga aparatur desa dan masyarakat desa Jagaraga memahami serta dapat melaksanakan tugas dan fungsi sebagai aparatur desa dengan baik, sehingga secara langsung atau tidak langsung akan sangat mempengaruhi keberhasilan pembangunan desa.

\section{DaftarPustaka}

Aljannah, Siti. 2014. Evaluasi Alokasi Dana Desa (ADD) Dalam Menunjang Pembangunan Desa Di Kecamatan Tambusai Utara Kabupaten Rokan Hulu.

Fajri, Rahmi dan Setyowati, Endah. Akuntabilitas Pemerintahan Desa Pada Pengelolaan Alokasi Dana Desa (ADD). Volume 3 (Nomor 7).

Faizatul Karimah, Choirul Saleh, Ike Wanusmawatie. Pengelolaan Alokasi Dana Desa Dalam Pemberdayaan Masyarakat (Studi Pada Desa Deket Kulon Kecamatan Deket Kabupaten Lamongan). Jurusan Administrasi Publik, Fakultas IImu Administrasi, Unifersitas Brawijaya, Malang. E-mail :faizatulkarimah@gmail.com Diakses 30 Desember 2018

Indrianasari, N. T. 2017. Peranan Perangkat Desa Dalam Akuntabilitas Pengelolaan Keuangan Desa. Jurnal IImiah IImu Akuntansi, Keuangan dan Pajak. Didownload https://media.neliti.com/media/publications/82749-ID-pengelolaan-alokasi-danadesa-dalam-pers.pdf Diakses 30 Desember 2018

Mardiasmo. 2004. Otonomi \& Manajemen Keuangan Daerah. Yogyakarta, Andi. 
Nurliana. 2013. Pengelolaan Alokasi Dana Desa (ADD) Dalam Pembangunan Fisik Di Desa Sukomulyo Kecamatan Sepaku kabupaten Penajam Paser Utara. EJurnal Administrasi Punblik.Volume 1 ( Nomor 3, 2013), 1059-1070.

Umami, Risya dan Nurodin, Idang.2017. Pengaruh Transparansi Dan akuntanbilitas Terhadap Pengelolaan Keuangan Desa.Volume 6.Edisi 11. Universitas Muhammadiyah Sukabumi. Diakses 29 Desember 2018

Link Akses :https://media.neliti.com/media/publications/78859-ID-pengelolaan-alokasi-danadesa-dalam-pemb.pdf https://www.researchgate.net/publication/314156933 dampak kebijakan alokasi dana desa Add Terhadap Pembangunan Desa Di Kabupaten Bulungan Tahu n 2011-2014. Diakses 30 Desember 2018 